\title{
VIKTOR TRAJKOVSKI, OUTSTANDING SWEDISH FRUIT-GROWING SCIENTIST
}

\section{BRIEF BIOGRAPHY}

Recently we said farewell to one of the leading fruit-growing scientists in Sweden, Viktor Trajkovski (17.11.194119.04.2018), who played a key role in the development of Latvian fruit-growing science at the end of the $20^{\text {th }}$ century and beginning of the $21^{\text {st }}$ century.

Viktor Trajkovski was born in Sofia, Bulgaria. In 1964, he acquired education by graduating the Agricultural University in Skopje, former Yugoslavia. To avoid the communist regime, he escaped to Sweden, where in 1968 he finished also Lund University. In 1970, he obtained a degree of horticulturist at the Swedish University of Agricultural Sciences (SLU), and in 1975 - a doctoral degree at SLU.

Most of his working life he spent at SLU, Division of Fruit Breeding, Balsgård. In 1973-1978, he was a black currant breeder, then senior lecturer. From 1978 to 2003, Viktor Trajkovski was the head of Balsgård Department of Horticultural Breeding (formerly Division of Fruit Breeding), SLU. In addition to his main work, he actively participated in different organisations of fruit-growing industry and science - he was the head of the Foundation of the Swedish Horticultural Eliteplantstation, Chairman of the Committee for Coordination of the Nordic Plant Breeding, Member of the Committee for Fruits and Berries at the Nordic Board for Plant Genetic Resources, member of Committee for evaluation of Plant Breeding Research in Finland, member of the Royal Swedish Academy of Agriculture and Forestry, member of the Lithuanian Academy of Sciences, member of the board of Swedish Pomological Society, etc.

In 2004, he together with his wife Karin Trajkovski founded the Swedish Pomological Science Centre, whose main lines of action are: 1) test- and demonstration fields and outdoor laboratories; 2) selection and breeding of superior varieties with a high content of bioactive compounds; 3 ) introduction of new fruit, berry, and nut varieties with added value in collaboration with plant breeders in the entire northern temperate zone; 4) evaluation in the fields of ancient fruit and berry cultivars traditionally grown in Sweden. He was the head of this Centre till his death.

Viktor Trajkovski was the supervisor of many postgraduate students from Sweden, Finland, Denmark, Norway, Lithua-

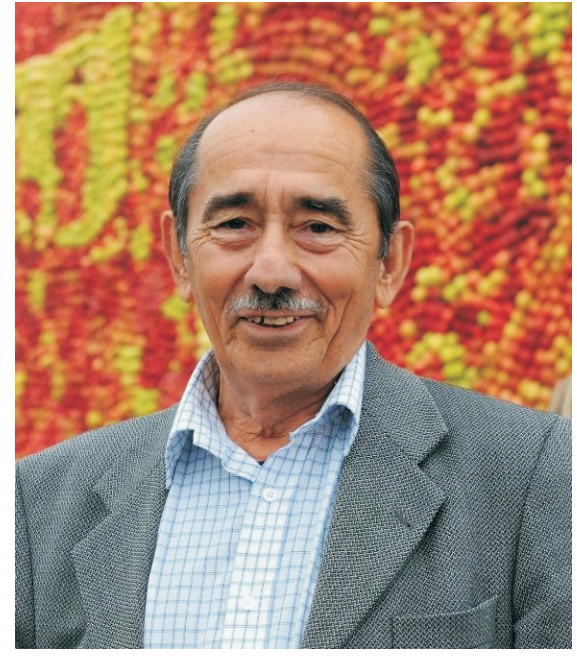

nia, and Latvia in pomology and fruit breeding, and also the chairman and member of committee of doctoral thesis examination. He was the author of more than 150 scientific publications and the co-ordinator for many national and international projects in the field of fruit breeding and fruit genetic resources. Viktor Trajkovski was the author or coauthor of three black currant, one gooseberry, six cherry and six plum cultivars. Plum cultivar 'Jubileum' is one of the most common cultivars in Nordic countries and during the last years also in Latvia.

\section{COOPERATION WITH LATVIAN HORTICULTURE SCIENTISTS}

Viktor Trajkovski and researchers from the Latvian Institute of Fruit Growing were brought together thanks to the interest of Nordic scientists about the developments in horticulture science in Baltic countries. In 1993, he organised a visit of Latvian and Lithuanian researchers to Sweden, and after a meeting with Dr. agr. Māra Skrīvele, cooperation developed very quickly. Every year scientists from the Horticulture Institute (former Dobele Horticulture Breeding Station) performed field work at Balsgård. The Balsgård Institute was an example for Latvian scientists, showing how to develop a research institution and its priorities. Viktor Trajkovski was a great teacher, always rich in new ideas. He never was arrogant, always willingly shared his knowledge and experience. In Latvia, the late 1990s and early 2000s 


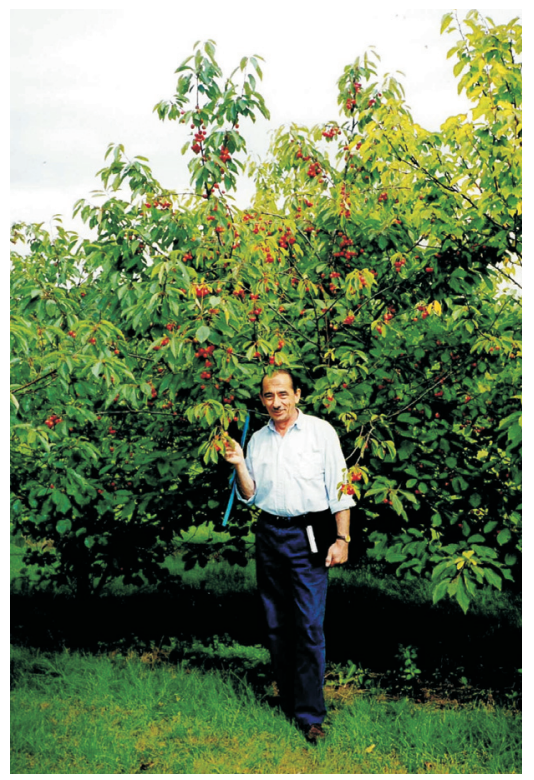

Viktor Trajkovski at his cultivar of sour cherry 'Kirsa' in Dobele, Latvia, 1998.

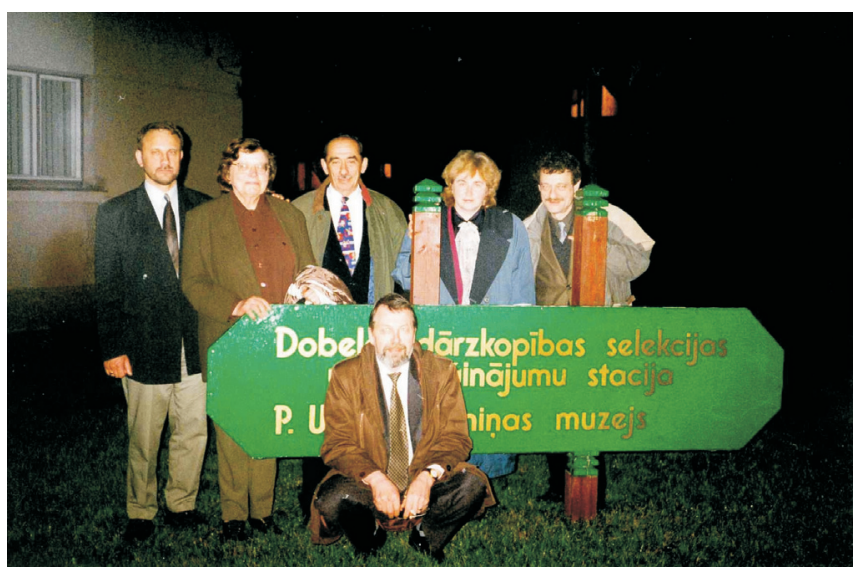

Viktor Trajkovski with Latvian colleagues at Dobele Horticultural Experimental Station (now Institute of Horticulture), 1999.

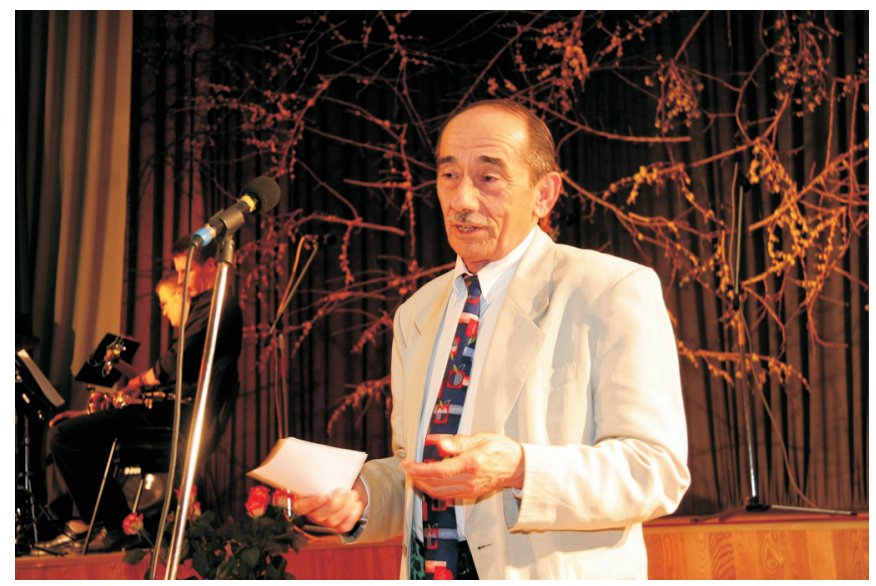

Welcome during the event of the $50^{\text {th }}$ anniversary of the Latvian Institute of Fruit Growing, Dobele, Latvia, 2006.

were a very hard period for science. Many research institutions were closed. Viktor Trajkovski has contributed largely to the fact that in Latvia the Latvian Institute of Horticulture, one of the leading institutions in horticultural science in the Baltic Sea region, still exists. He not only helped with advice and know-how, but also supported the Institute materially by involving it into different projects, helping to obtain modern research equipment, etc.

Viktor Trajkovski initiated participation of Latvian scientists in several international projects in horticulture. Basing on the experience obtained during these projects, in the following years researchers of the Institute of Horticulture carried out a number of national projects in fruit crop breeding, growing system research, as well as fruit and berry processing. It is hard to overestimate the role of Viktor Trajkovski in the involvement of Latvian scientists into international science activities. Thanks to his initiative the Institute became a member of several international horticulture organisations, started participation in COST actions and international research projects.

INTERNATIONAL SCIENTIFIC PROJECTS TOGETHER WITH VIKTOR TRAJKOVSKI

European $4^{\text {th }}$ Framework project "Japanese Quince (Chaenomeles japonica), a New European Fruit Crop for Production of Novel Juice, Flavour and Fibre" (1995-2000). Participating countries: Sweden, France, Spain, Lithuania, Latvia, Finland.

The project of the Swedish Research Council "Breeding of Black Currant Varieties Suitable for Organic Production" (1997-2001). Participating countries: Sweden, Russia, Latvia, Lithuania.

The project of the Swedish Research Council "Breeding of New Plum and Cherry Varieties" (1998-2000). Participating countries: Sweden, Latvia.

The project of the Swedish Research Council "Characterization of fruit plant genetic resources in Sweden and Latvia: Malus sp." (1997-2000). Participating countries: Sweden, Latvia.

PhD training programme for Baltic PhD Students, the Royal Swedish Academy of Agriculture and Forestry, "Characterisation of Latvian and Swedish Sweet and Sour Cherry Genetic Resources" (2000-2005). PhD student from Latvia Gunārs Lācis. Supervisors: Viktor Trajkovski, Sweden; Amy Iezzoni, USA; Isaak Rashal, Latvia; Edīte Kaufmane, Latvia.

\section{RESULTS OF COMMON BREEDING PROGRAMMES}

In 1996, SLU-Balsgård Dept of Horticultural Plant Breeding and the Dobele Horticulture Breeding Station signed an agreement for starting a common fruit and berry crop breeding programme. Targeted crosses were made for blackcurrants, autumn raspberries and plums at both institutions, using the results of joint genetic material evaluation.

After 2004, when Viktor Trajkovski founded the Swedish Pomological Science Centre, his cooperation with Latvian scientists continued. As a result of common breeding work, 


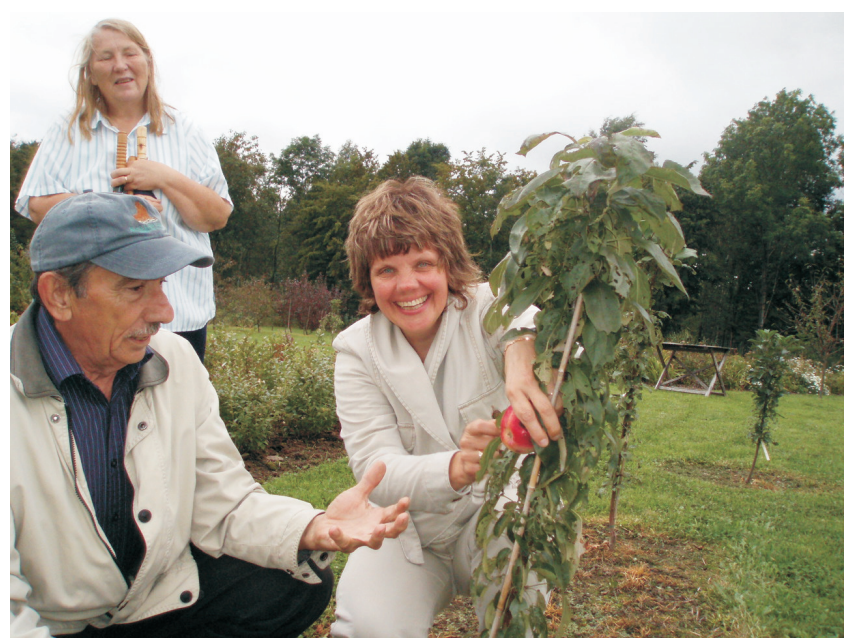

Near a Latvian apple cultivar in the garden of Swedish Pomological Science Centre, Stubbaröd, Sweden, 2005.

several cultivars were registered in Latvia and Lithuania. Of these, three plum cultivars - 'Ance', 'Adelyn', and 'Sonora', black currant cultivar 'Karina', and raspberry cultivar 'Viktorija' were registered in Latvia; black currant cultivars 'Ritmo', 'Domino' and 'Viktor' — in Lithuania. Several plum, pear and apple cultivars still are passing the DUS test for registration in Latvia.

\section{SCIENTIFIC PUBLICATIONS TOGETHER WITH LATVIAN RE- SEARCHERS}

1. Butac, M., Bozhkova, V., Zhivondov, A., Milosevic, N., Bellini, E., Nencetti, V., Blazek, J., Balsemin, E., Lafarque, B., Kaufmane, E., Gravite, I., Vasiljeva, M., Pintea, M., Juraveli, A., Webster, T., Hjalmarsson, I., Trajkovski, V., Hjeltnes, S. H. (2012). Overview of plum breeding in Europe. Acta Hortic., 981, 91-98.

2. Ikase, L., Trajkovski, V. (2001). The Swedish-Latvian Malus genetic resources research program. In: Broad Variation and Precise Characterization - Limitation for the Future. EUCARPIA Section Genetic Resources, Poznan, pp. 38-39.

3. Kaufmane, E., Grāvīte, I., Trajkovski, V. (2012). Results of Latvian plum breeding programme. Acta Hortic., 968, 55-60.
4. Lacis, G., Kaufmane, E., Kota, I., Gravite, I., Trajkovski, V. (2012). Genetic diversity and plasticity in selected progeny of plum cultivar 'Jubileum'. Acta Hortic., 935, 129-135.

5. Lacis, G., Kaufmane, E., Trajkovski, V. Rashal, I. (2009). Morphological variability and genetic diversity within Latvian and Swedish sweet cherry collections. Acta Universitatis Latviensis, 753, 19-32.

6. Lacis, G., Rashal, I., Ruisa, S., Trajkovski, V., Iezzoni, A. F. (2009). Assessment of genetic diversity of Latvian and Swedish sweet cherry (Prunus avium L.) genetic resources collections by using SSR (microsatellite) markers. Scientia Horticulturae, 121, 451-457.

7. Lacis, G., Rashal, I., Trajkovski, V. (2010). Comparative analysis of sweet cherry ( $P$. avium) genetic diversity revealed by two methods of SSR marker detection. Proc. Latvian Acad. Sci., Section B, 64 (3/4), 149-158.

8. Lacis, G., Trajkovski, V., Rashal, I. (2010). Phenotypical variability and genetic diversity within accessions of the Swedish sour cherry (Prunus cerasus L.) genetic resources collection. Biologija, 56 (1/4), 1-8.

9. Lacis, G., Kaufmane, E. Rashal, I., Trajkovski, V., Iezzoni, A. F. (2008). Identification of self-incompatibility $(S)$ alleles in Latvian and Swedish sweet cherry genetic resources collections by PCR based typing. Euphytica, 160, 155-163.

10. Lācis, G., Kaufmane, E., Kota, I., Grāvīte, I., Trajkovski, V. (2012). Genetic diversity and plasticity in selected progeny of plum cultivar 'Jubileum'. Acta Hortic., 935, 129-135.

11. Lācis, G., Rashal, I., Trajkovski, V. (2011). Implementation of a limited set of SSR markers for screening of genetic variability in Latvian and Swedish sour cherry (Prunus cerasus L.) genetic resources collections, Proc. Latvian Acad. Sci., Section B, 65 (1/2), 21-28.

12. Sasnauskas, A., Trajkovski, V, Strautina, S., Tikhonova, O., Šikšnianas, T., Rubinskienè, M., Viškelis, P., Lanauskas, J.,Valiuškaitė, A., Rugienius, R., Bobinas, Č. (2009). Evaluation of blackcurrant cultivars and perspective hybrids in Lithuania. Agron. Res., 7 (2), 737-743.

13. Strautina, S., Krasnova, I., Kalnina, I., Sasnauskas, A., Trajkovski, V., Tikhonova, O. (2012). Results of the common international breeding program for blackcurrant. Acta Hort., 926, 53-58.

14. Trajkovski, V., Strautina, S., Sasnauskas, A. (1998). Breeding for hardiness and resistance in black currants. Horticulture and Vegetable Growing (Babtai), 17 (3), 150-158.

Edìte Kaufmane,

Laila Ikase

Institute of Horticulture

\section{VIKTORS TRAJKOVSKIS - IZCILS ZVIEDRU AUGLKOPĪBAS ZINĀTNIEKS}

Rakstā sniegta izcilā zviedru aug̣̣kopības zinātnieka Viktora Trajkovska (Viktor Trajkovski, 1941-2018) īsa biogrāfija un aprakstīts viṇa ieguldījums aug̣̣kkopības pētījumu veicināšanā Latvijā. 